\title{
ESSAY
}

\section{Drawing as Radical Multimodality: Salvaging Patrick Geddes's Material Methodology}

\section{Rachel Hurdley}

Cardiff University

\author{
Mike Biddulph \\ Cardiff City Council \\ Vincent Backhaus \\ University of Cambridge
}

\section{Tara Hipwood}

Cardiff University

\section{Rumana Hossain}

University of Leeds and Jahangirnagar University

This essay, which is accompanied by a collective online sketchbook on the American Anthropologist website, is about drawing as a research methodology. ${ }^{1}$ Drawing, like writing, is a craft that can be learned. It is a radical social research method, recalling the lost, undisciplined roots of research into "folk, work, place" in Britain-roots that we explore this essay explores through the Foundations of British Sociology: The Sociological Review Archive at Keele University (Keele University 2010). Too many scholars now research "materiality" as an armchair topic. Multimodality_a young, cross-disciplinary, and still unformed aggregation of research topics, designs, methods, and methodologies - is threatened by the haste to adopt ever-new technologies. Through "slowest" practice, we can begin to understand, first, how salvaged methodologies might transform current practices, and, second, how human capacities are limited, channeled, and lost in the race to innovate. Through practicing and developing material methodology, researchers can reshape dominant theories of modernity, since how we make knowledge is critical for fashioning alternative pasts, presents, and futures.

Materials relating to key activists and opinion shapers of the early twentieth century, including Patrick Geddes, Victor Branford, Francis Galton, H. G. Wells and Lewis Mumford, are cataloged in the Foundations of British Sociology: The Sociological Review Archive stored at Keele University in the United Kingdom. This archive comprises "valuable materials on the origins of modern British sociology, and related social sciences such as social psychology, cultural geography, town planning and demography” (Keele University 2010). 
Until recently, this collection was a forgotten history (Evans 1986), partly because it was fully accessible only after it was cataloged in 2008-10. Another reason is Geddes's failure to become the first chair in sociology at the London School of Economics and his consequent marginalization (Studholme 2008).

Altogether lacking disciplinary boundaries, these intersecting (sometimes happenstance) circles of family, friends, business associates, charity organizations, and acquaintances suggest a pragmatic networking practice that was aimed at action in the civil sphere. This was a "sociable" research venture. Their connections with the Chicago ethnographers, natural science methodologies, and urban renewal programs demonstrate the international and innovative possibilities of their "amateur" approach (Lybeck 2013). To use the term "interdisciplinary" would be wrong, since "discipline" was not the field of practice but rather the problem at hand, which, as Mills (1959) stated, should be the catalyst for selecting methods and data.

Geddes's and Branford's vision, “drawing on geography, anthropology, economics and urban planning, in addition to sociology," sought to engage public cultural imaginations through theater and visual arts (Scott and Bromley 2013, 295). While academic sociology in Britain developed over the twentieth century into the study of modernity in terms of the nation-state and centralized governance, Geddes's network, with their regionalist, activist, nondisciplinary social science, was marginalized due to philosophical and personal differences between key groups and individuals. Thus, this ambitious project to transform social life through detailed fieldwork, radical theory building, and public spectacle, which could move buildings, fill streets with pageantry, and exhibit the world in a tower, disappeared. Geddes's generalist approach and overcomplexity in his methodology have been criticized (Law 2005). However, new emphases on public, environmental, and regionalist approaches of the studies (Scott and Bromley 2013) and the porosity of this social science, particularly in its relations with biological sciences (Renwick 2012), suggest the salience and timeliness of the archive to rethinking current social scientific practice.

The members of the Sociological Society and associated groups were deliberately $a$ disciplinary and publicly engaged, especially in their pursuit of "eutopian" (as Geddes spelled it) civic renewal. Their cosmopolitanism and internationalism involved links with North American universities, including the University of Wisconsin, Yale University, the University of Michigan, and the University of Toronto (Scott and Bromley 2013). They influenced and learned from close contacts, including Marcel Mauss, Lewis Mumford, Thorstein Veblen, and Albion Small. In particular, their concept of the city as laboratory, pragmatic use of multiple 
empirical research methods, and "democratic ethos" resonated with the concerns of the nascent Chicago School of Sociology (Bulmer 1984, 22).

As Ingold (2011) points out, too many scholars now research "materiality" without doing or making anything with materials. Proliferating social media platforms, ongoing debates over what constitutes a mode/modality, the dominance of video analysis, and the persistant problematic of its social semiotic ancestry cause agitation that is not always fruitful. Any search for "drawing" within the subject more often leads to phrases deriving, broadly, from the older meaning of the verb (to pull) than the newer sense of making a picture. The Foundations of British Sociology: The Sociological Review Archive, which includes papers, photographs, slides, sketches, graphs, woodcuts, paintings, maps, and diagrams, offers multiple possibilities for restoring material methodology. In redoing these "slowest" practices, we can begin to understand how salvaging methodologies might transform current practices. We can also contemplate how human capacities are limited, channeled, and lost in the fourth industrial revolution (Peters 2017).

This essay therefore focuses on the act of making slowly through drawing, rather than pulling in and from too many directions, too fast. It is not a conventional scholarly narrative in a common language, but a sketchbook, on paper and screen, made by people with diverse biographic, cultural, and disciplinary backgrounds. The project emerged partly from an ongoing collaboration between Rachel Hurdley, a cultural sociologist, and Mike Biddulph, an urban designer and fine artist, exploring how different social scientific disciplines use (or do not use) drawing. It also draws on Rachel's ongoing research into The Foundations of British Sociology: The Sociological Review Archive with literary studies scholar, David Amigoni, at Keele University. The online section, available on the American Anthropologist website, is a multidisciplinary reflection on drawing by five workshop participants. Annual workshops with postgraduate research students explore whether and how drawing might contribute to their work. By bringing together our reflections from these workshops, our aim is to encourage others to draw so that a wider body of practices might be established, shared, and debated. As such, the collaboration is a first look back at these roots of British social sciences as practiced by Patrick Geddes and his network in the early years of the twentieth century (Geddes 1905). This essay first considers the place of drawing within the development of contemporary qualitative and multimodal methods. Second, it connects drawing as a radical methodology to Geddes's eclectic, networked approach to understanding "folk, work, place." In conclusion, it suggests that revisiting these early "sociable" methods could ground multimodality — and modernity—in material methodology. 


\section{DRAWING IN CONTEXT}

Although some sociologists and anthropologists have been critical of the visual as being a dominant sense, leaving smell, touch, taste, and hearing as subordinate senses (Classen 2005; Howes 2005; Manalansan 2006), this ignores the ability of vernacular or everyday practices of drawing and sketching to interpret, communicate, or share something that escapes verbal evocation. Drawing is democratizing (Degarrod 2016; Douglas et al. 2014; Theron et al. 2011). It is a practice almost everyone can do, and is beyond language, yet it is too often seen as kindergarten play or requiring a special "innate" creativity and dexterity (Edwards 2012). Despite the long history of sketching in anthropological fieldwork (Urry 1972), the practice declined due the increasing speed and ease of photography (Soukup 2014).

Asking research participants, particularly young people, to make sketches is a common method of elicitation in social research (Bagnoli 2004; Knight et al. 2016; Mannay 2015). However, it is unusual to find drawings beyond the sketchbook or journal, with some notable exceptions (Gell 1999; Taussig 2011), whereas disseminating through writing, talk, video, or photography is taken for granted (Hurdley and Dicks 2011). In particular, key multimodal texts have treated drawing as products made by research participants (especially children) or as part of a particular discourse for detailed analysis (Jewitt et al. 2016; Kress 2009; Kress and Van Leeuwen 2001; Machin 2016; Mavers 2010; ). In multimodal studies, the process of drawing is captured on video camera, with the researcher as observer (Norris 2011). This observational detachment is treated as incommensurable with ethnography by Pink (2011), but scholars at the intersection of ethnography and multimodality recognize the potential in working with the frictions, crossings, and misalignments between the two approaches (Dicks et al. 2011). Becoming practitioners of drawing attunes scholars to the multivalent, ambiguous modalities of exercising eyes, hand, pen, and paper. Group activity, either by working on individual images or collaborative images, can also encourage reflective conversations. Drawings afford different modalities from photographic/video data, allowing alternative analytic themes to emerge.

Garner's (2012) edited collection by drawing makers and drawing researchers is a timely provocation to treat the practice "as a rigorous and distinctive area of creative practice" rather than a prelude or handmaiden to some greater or newer venture (see also Taylor 2012). Drawing, like writing, is a craft that can be learned (Edwards 2012). Although scholars continue to theorize without doing (for example, Guggenheim 2015), those of us who have stepped out of the customary academic keyboard "hunch" are finding how our "looking" has 
changed (Causey 2016; Morgan Centre 2016). The practice of drawing makes us vulnerable; it changes our habitus as embodied, reflexive researchers and rebalances power relations between the "expert" and the research participant. Drawing with participants, daring to make - and leave - mistakes on the page, is a humane, human practice. Nevertheless, as a technology, it can be (and has been) a valuable propaganda tool, traveling and metamorphosing through histories and cultures (Thomas 1997, 520; Wood 2000). Berger's (1972) book draws attention towards "ways of seeing," compelling the viewer to consider how she looks at an artwork-what assumptions she makes about her place in the world.

Drawing is a simple method for getting to know a research site, stimulating active looking. For example, a quick observational sketch of a place on paper or on a tablet is less intrusive than a photograph, and is often more useful for noting positioning and movement of people and things. Spending time on a drawing can engage participants so they are more invested and interested in a research project. But drawing is more than a tool in a researcher's toolkit, as some textbooks persist in calling research methods (Hurdley, forthcoming). Like writing, it is a methodology: a way of thinking and doing research that shapes what knowledge and meanings are produced (Scott Shields 2016). Drawing with others is an exercise in trust. As academics, writing - often by tapping on a tablet or keyboard, often alone - is our habitus. Sitting with a pad of paper and a pen or pencil at a desk or on our lap changes us, as it changes our bodies, our relations with our materials, how we think, and how people approach us. It is frightening to pin up our first efforts on a display board. The judgment of our research informants or our peers is instant. Yet if we trust, as a group, that we will be generous, thoughtful, and open, then allowing vulnerability—woundability—enables a different kind of intimacy to emerge (Butler 2004).

Drawing also opens our eyes to a different kind of looking, even a different mode of shaping the world. Sitting and looking at a familiar object, such as the clock on the mantelpiece or the doorway one has entered a thousand times, makes it strange. Ghosts are caught in lines tracing remembered landscapes and faces. Drawing performs pasts, presents, and futures. Early attempts to draw what is before our eyes reveal how "observation" routinely relies on memory, imagination, and assumption. Any disruption of the customary logic of practice (Bourdieu 1990) not only questions how we see but also how we know. This is the foundation of methodology: What do we do to understand and explain social worlds?

Many scholars, armored in the authority of the word, forget how their confident infant hands clutched crayon, brush, and pencil. As Michael Taussig commented, "But drawing, for the amateur? off limits. Drawing is precious in every sense of the word, except for the 
'Littlies"” (2011, 33-34; also Dewey 1934). Returning to this practice forces us to move out of the customary scholarly field of writing, out of our comfortable methodology.

Remembering modes of social inquiry, forgotten in conventional histories of academic social science disciplines, such as that of the Sociological Society in the UK, offers another route into "ordinary" modernity. Suddenly, we are part of something that is not part of the World Wide Web; we can choose not be caught up in the dominant network of digital, disciplined scholarliness (Berger 2001).

\section{DRAWING TOGETHER PAST AND POSSIBLE SOCIAL SCIENCES}

Geddes and his circle employed graphic representation to survey urban areas, from their geology to their kitchen tables. They pursued these multiple processes of inquiry and engagement with the objective of civic renaissance through cultural engagement. In particular, visualizations, often for public exhibition or reading, were strikingly different from the British sociology that emerged from universities. Their methodology for addressing what Geddes called the "neotechnic" challenge of modernity was eclectic and founded upon principles of action and unity. Methods of knowledge exchange and data collection, analysis, and representation included regional surveys (from geology to mapping public lavatories and measuring milk production), photography, "Thinking Machines," woodcuts, drawings, diagrams, letters (often revised with marginalia), poems, photographs of European villagers and poor households in Chester, watercolors, pamphlets, and the first British sociology journal. The way they remade modernity through a modernist aesthetic offers kaleidoscopic potential for renewing research imaginations.

[FIGURE 1a and 1b ABOUT HERE]

Geddes's "Thinking Machine" and the watercolor image (Figure 1a and 1b) show how making simple graphics on a scrap of paper, revising, and redrawing were acts in a cumulative, shared reimagining of a capital city. "Action" was not limited to the page or a closed membership; utopianism was more than an idea. Geddes was instrumental in moving Thomas More's house, Crosby Hall, from its neglected position in Bishopsgate to Chelsea, where it housed Belgian refugees and became the first women's residence hall for the University of London. It was to be the center of an urban prototype, envisioned in an exhibition but not (yet) fulfilled. Civic pageants in Edinburgh, meetings of the "Utopians" group in Chelsea, Geddes's Outlook Tower museum/laboratory, and educational trips were only a few of the group's public activities. Around this, Geddes and his companions planned 
an urban renaissance based on humanist principles in both civic design and democratic education.

Although the highly visual character of the archive materials is highlighted by Scott and Bromley (2013), elements such as these require practice, rather than comment, for a full realization of their potential impact on contemporary social sciences. Geddes's holism, however flawed, was untamed by the atomizing of disciplines and anatomizing of textbooks, which have left research practices in fragments. According to Foucault, "There is no point in adopting a protectionist attitude. . . . Rather, we must multiply the paths and the possibilities of coming and goings" (1996, 305). An initial examination with David Amigoni of predisciplinary methodologies within the Foundations of British Sociology: The Sociological Review Archive materials provoked curiosity. How might these transfer into contemporary research designs? How realistic is the implementation of a "slow" methodology, which as far as possible does not use new technological instruments? As the social sciences become dominated by discourses of consumerist individualization, political disengagement, and global inequalities, there is a pressing need to reinvigorate and research habitus and imaginations (Pohoryles 2017; Ravetz and Ravetz 2017).

With this intention, my colleague Mike Biddulph and I organized the first crossdisciplinary Cardiff Drawing Workshop for research students, which led to the sketchbook, available on the American Anthropologist website. Each workshop is different; in 2017, two geography research students, Tara Hipwood and Lucy Baker, an architect and a fine artist in previous lives, facilitated the workshop with me, reflecting on how treating drawing as a research method inflected their accustomed drawing practices. For the first time, researchers in linguistics and creative writing, whose disciplines are entirely text-based, participated. Yet they too seek to envision their research designs, novel structures, and imagined worlds differently, relying less on writing. Several participants will move from desk to easel in the fall for drawing classes, since their skills do not yet match their excitement about this methodology. For that is what emerges from our discussions: thinking through drawing transforms how we do research. The question is: How do we change when we work as both "research practitioners" and "arts practitioners?" Lucy, an artist first and researcher second, states that "research has informed a greater understanding of my subjects/topics of interest and what is going on when I am making art in place, but essentially I haven't changed and my interests haven't changed-I understand them more critically and broadly" (Baker 2017). The "novice artists" also commented on an expansion of understanding, critical reflexivity, and an opening up — rather than reinforcing — of disciplinary borders. This is not hybridity, since, as 
Strathern argues, "hybrids that appear able to mix anything can serve as boundaries to claims" (1996, 531). Lucy argues that "a visual representation is different to textual information; it situates a viewer in place through a different sensory engagement with that knowledge, requires craft and skill" (see also Gell 1992). Rooted in arts practice, flourishing also from the graft of social scientific research, she is skilled in both disciplines. It is the oscillation between these identities, the rootedness and growing, that produces her particular ways of making meaning. As researchers, we cannot be artists without serious endeavor, from learning the principles of drawing to prolonged practice.

\section{CONCLUSION}

The essay has explored how drawing, as practice and as cultural material, calls into question taken-for-granted logics. Sitting down with pen and paper or standing at an easel, looking at what seems so familiar in order to draw it, brings home how much is forgotten when writing and talking dominate methodology. Similarly, concepts caught up in words so intricate they form a labyrinth of confusion seem clearer when expressed graphically (in its other sense). Historic images powerfully demonstrate not only the importance of culturally specific analysis but also how drawing is a world-changing technology. Audiovisual technologies and the vast potential of social media offer so much to ethnography and other research methodologies, but these are always subject to the politics of consumption. Multimodality, a young and still unformed thing — neither a discipline nor a methodology, but more a growing collection of case studies and musings - is constantly on the move. Yet the rapidity of this growth and its nurture by so many eager hands threatens its long-term survival. Returning to the lost roots of eclectic, sociable, and undisciplined material methodology can ground itand us. As a first step, learning to draw and disseminating research through drawing facilitates this radical return because it is simple, but requires practice and understanding to develop the craft. Twenty-first-century technology beguiles us because anyone with a smartphone can make a film, edit a photograph, produce a soundscape or multimedia blog. Scholars practiced in the skills of writing must become apprentices in these ways of making and representing meaning before overburdening the tender shoots of multimodality with more fragile grafts. Moreover, as the expanding capacity and intelligence of new technologies challenge assumptions about what it means to be human (Peters 2017), it is surely time to review how those meanings are made by scholarly—human—bodies.

[FIGURE 2 ABOUT HERE] 


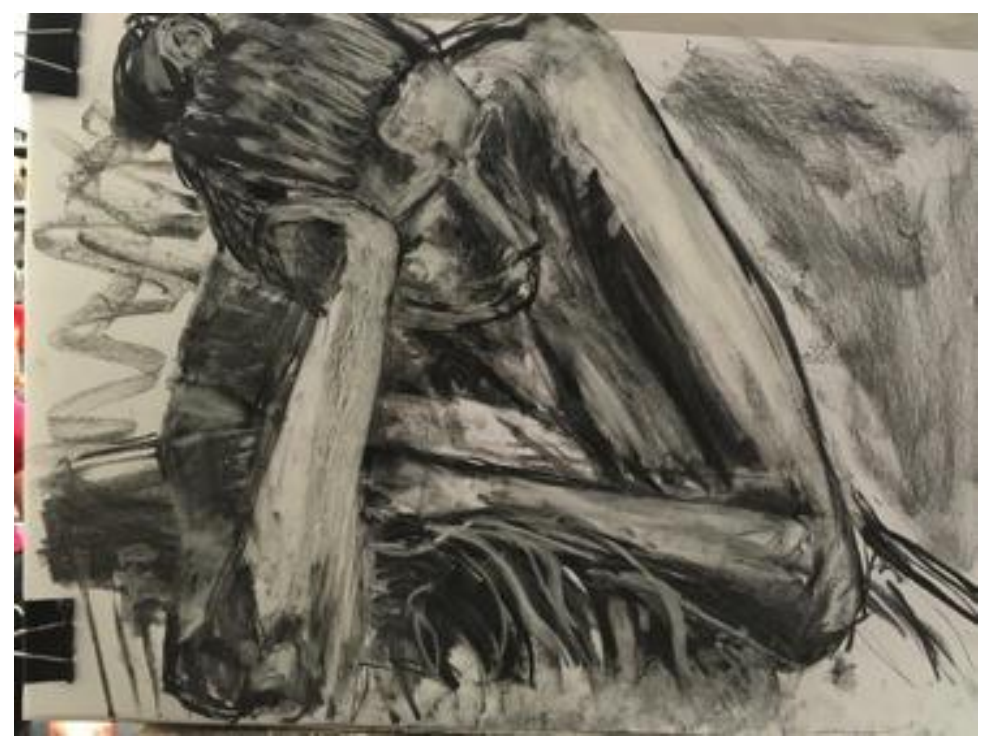

I am vulnerable when I draw; when we draw together, we trust each other to be generous. It takes time to learn to draw because learning to look takes time. Hand and eye, pen(cil) and paper or toes in the sand make the world differently by making us different. The blank paper becomes a humane material, the charcoal and pastel opened out into lines, light, volumes, and shadows, as Pip's presence fills the time and space between us (Figure 2). A click with a smartphone is, in a way, trapped between the period piece of the snapshot (such an aggressive word) and the haste of late modernity. Time is a consumer good in that world. But here, time breathes as space unfurls.

\section{NOTES}

${ }^{1}$ This essay is dedicated to John Clayton (1975-2016).

\section{REFERENCES CITED}

Bagnoli, Anna. 2004. "Researching Identities with Multi-Method Autobiographies." Sociological Research Online 9 (2): n.p. http://www.socresonline.org.uk/9/2/bagnoli.html.

Baker, Lucy 2017. "Drawing and Research: An Artist's Perspective." Presentation to the ESRC DTP Drawing as Method workshop, Cardiff University, June 19.

Berger, John. 1972. Ways of Seeing. Harmondsworth: Penguin. 
Berger, John. 2001 The Shape of a Pocket. London: Bloomsbury.

Bourdieu, Pierre. 1990. The Logic of Practice. Stanford, CA: Stanford University Press.

Bulmer, Martin. 1984. The Chicago School of Sociology: Institutionalization, Diversity, and the Rise of Sociological Research. Chicago: University of Chicago Press.

Butler, Judith. 2004. Precarious Life: The Powers of Mourning and Violence. London: Verso.

Causey, Andrew. 2016. Drawn to See: Drawing as an Ethnographic Method. Toronto:

University of Toronto Press.

Classen, Constance. 2005. "Touch in the Museum.” In The Book of Touch, edited by Constance Classen, 275-86. Oxford: Berg.

Degarrod, Lydia Nakashima. 2016. "Collaborative Art and the Emergence and Development of Ethnographic Knowledge and Empathy." Critical Arts 30 (3): 322-40.

Dewey, John. 1934. Art as Experience. New York: Minton Balch \& Company.

Dicks, Bella, Rosie Flewitt, Lesley Lancaster, and Kate Pahl, eds. 2011. "Special Issue: Multimodality and Ethnography: Working at the Intersection" Qualitative Research 11 (3): $227-346$.

Douglas, Anne, Amanda Ravetz, Kate Genever, and Johan Siebers. 2014. "Why Drawing, Now?" Journal of Arts \& Communities: 6 (2-3): 119-31.

Edwards, Betty. 2012. Drawing with the Right Side of the Brain. Harmondsworth: Penguin.

Evans, David F. T. 1986. "Le Play House and the Regional Survey Movement in British Sociology 1920-1955." Master's thesis, City of Birmingham Polytechnic, UK. 
Foucault, Michel. 1996. “The Masked Philosopher.” In Foucault Live (Interviews, 19611984), edited by Sylvère Lotringer, 302-07. New York: Semiotext(e).

Garner, Steve, ed. 2012. Writing on Drawing: Essays on Drawing Practice and Research. Bristol: Intellect.

Geddes, Patrick. 1905. “Civics: As Applied Sociology.” Sociological Society: Sociological Papers 1904-1906, 103-18. London: Macmillan.

Gell, Alfred. 1992. "The Technology of Enchantment and the Enchantment of Technology." In Anthropology, Art \& Aesthetics, edited by Jeremy Coote and Anthony Shelton, 40-66. Oxford: Oxford University Press.

Gell, Alfred. 1999. The Art of Anthropology: Essays and Diagrams. Edited by Eric Hirsch London: Athlone.

Guggenheim, Michael. 2015. “The Media of Sociology: Tight or Loose Translations?” The British Journal of Sociology 66 (2): 345-72.

Howes, David. 2005. "Introduction: Empires of the Senses." In Empire of the Senses: The Sensual Culture Reader, edited by David Howes, 1-17. Oxford: Berg.

Hurdley, Rachel. 2014. "Synthetic Sociology and the 'Long Workshop': How Mass Observation Ruined Meta-Methodology.” Sociological Research Online 19 (3): n.p.

Rachel. Forthcoming. "Drawing as Method." In Sage Research Methods Cases, edited by Jamie Lewis.

Hurdley, Rachel, and Bella Dicks. 2011. "In-Between Practice: Working in the "Thirdspace" of Sensory and Multimodal Methodology." Qualitative Research 11 (3): 277-92.

Ingold, Tim, ed. 2011. Redrawing Anthropology: Materials, Movements, Lines. London: Routledge. 
Jewitt, Carey, Jeff Bezemer, and Kay O'Halloran. 2016. Introducing Multimodality London: Routledge.

Keele University. 2010. "Foundations of British Sociology: The Sociological Review Archive.” Keele: Keele University Library Special Collections and Archives. https://calmview.keele.ac.uk/CalmView/Aboutcatalogue.aspx.

Knight, Linda, Lyn Zollo, Felicity McArdle, Tamara Cumming, Jane Bone, and Avis Ridgway. 2016. "Drawing Out Critical Thinking: Testing the Methodological Value of Drawing Collaboratively." European Early Childhood Education Research Journal 24 (2): $320-37$.

Kress, Gunther. 2009. Multimodality: A Social Semiotic Approach to Contemporary Communication. London: Routledge.

Kress, Gunther, and Theo Van Leeuwen. 2001. Multimodal Discourse. London: Oxford University Press.

Law, Alex. 2005. "The Ghost of Patrick Geddes: Civics As Applied Sociology.” Sociological Research Online 10:2. http://www.socresonline.org.uk/10/2/law.html.

Lybeck, Eric. 2013. "Lester Ward and Patrick Geddes in Early American and British Sociology." History of the Human Sciences 26 (2): 51-69.

Machin, David. 2016. Introduction to Multimodal Analysis. London: Bloomsbury

Manalansan, Martin. 2006. "Immigrant Lives and Politics of Olfaction in the Global City." In The Smell Culture Reader, edited by Jim Manalansen, 41-52. Oxford: Berg.

Mannay, Dawn. 2015. Visual, Narrative and Creative Research Methods: Application, Reflection and Ethics. London: Routledge. 
Mavers, Diane. 2010. Children's Drawing and Writing: The Remarkable in the Unremarkable. London: Taylor \& Francis.

Mills, Charles Wright. 1959. The Sociological Imagination. Oxford: Oxford University Press.

Morgan Centre, Manchester University. 2016. "Sketching Research Project." http://projects.socialsciences.manchester.ac.uk/sketching-research/.

Norris, Sigrid, ed. 2011. Multimodality in Practice: Investigating Theory-in-Practicethrough-Methodology. London: Routledge.

Peters, Michael. 2017. “Technological Unemployment: Educating for the Fourth Industrial Revolution." Educational Philosophy and Theory 49 (1): 32-41.

Pink, Sarah. 2011. "Multimodality, Multisensoriality and Ethnographic Knowing: Social Semiotics and the Phenomenology of Perception." Qualitative Research 11 (3): 261-76.

Pohoryles, Ronald. 2017. "Back to the Future? From Pragmatic Approaches in the Social Sciences to the Development of the Patchwork Theory." Innovation: The European Journal of Social Science Research 30 (1): 5-23.

Ravetz, Joe, and Amanda Ravetz. 2017. "Seeing the Wood for the Trees: Social Science 3.0 and the Role of Visual Thinking." Innovation: The European Journal Of Social Science Research 30 (1): 104-20.

Renwick, Christopher. 2012. British Sociology's Lost Biological Roots: A History of Futures Past. London: Palgrave.

Scott, John, and Ray Bromley. 2013. Envisioning Sociology: Victor Branford, Patrick Geddes and the Quest for Social Reconstruction. New York: State University of New York Press.

Scott Shields, Sara. 2014. "Process as Growth." https://www.youtube.com/watch?v=zGUj6Ilfjis 
Scott Shields, Sara. 2016. "How I Learned to Swim: The Visual Journal as a Companion to Creative Inquiry." International Journal of Education \& the Arts 17 (8): 1-25.

Soukup Martin. 2014. "Photography and Drawing in Anthropology." Slovak Ethnology 4 (62): 534-46.

Strathern, Marilyn. 1996. "Cutting the Network." The Journal of the Royal Anthropological Institute 2 (3): 517-35.

Studholme, Maggie. 2008. "Patrick Geddes and the History of Environmental Sociology in Britain: A Cautionary Tale.” Journal of Classical Sociology 8 (3): 367-91.

Taussig, Michael. 2011. I Swear I Saw This: Drawings in Fieldwork Notebooks, Namely my Own. Chicago: University of Chicago Press.

Taylor, Anita. 2012. "Foreword." In Writing on Drawing: Essays on Drawing Practice and Research, edited by Steve Garner, 9-11. Bristol: Intellect Books.

Theron, Linda, Claudia Mitchell, Ann Smith, and Jean Stuart, eds. 2011. Picturing Research: Drawing as Visual Methodology. Rotterdam: Sense Publishers.

Thomas, Hugh. 2006. The Slave Trade: History of the Atlantic Slave Trade, 1440-1870. New York: Simon \& Schuster.

Urry, John. 1972. “'Notes and Queries on Anthropology' and the Development of Field Methods in British Anthropology, 1870-1920.” Proceedings of the Royal Anthropological Institute of Great Britain and Ireland 1972:45-57.

Wood, Marcus. 2000. Blind Memory: Visual Representations of Slavery in England and America. London: Routledge.

\section{FIGURE CAPTIONS}


Figure 1. (a) Painted suggestion for use of vacant space in Chelsea c. 1916; (b) notes and Thinking Machine regarding survey of Chelsea 1908-c. 1916 (GB172 LP/4/3/1/1/25 and GB172 LP/4/1/1/1/11/2). (Reproduced with permission from The Foundations of British Sociology Archive, Keele University Library)

Figure 2: Pip, 2016. (Drawing courtesy of author) 